\title{
Microenvironmental Rigidity of 3D Scaffolds and Influence on Glioblastoma Cells: A Biomaterial Design Perspective
}

\author{
Ilaria Elena Palamà ${ }^{*}$, Stefania D'Amone ${ }^{1}$ and Barbara Cortese ${ }^{2 *}$ \\ ${ }^{1}$ Nanotechnology Institute, CNR-Nanotechnology Institute, Lecce, Italy, ${ }^{2}$ Nanotechnology Institute, CNR-Nanotechnology \\ Institute, University La Sapienza, Rome, Italy
}

Keywords: 3D scaffolds, glioblastoma, stiffness, neurospheres, microenvironment

\section{INTRODUCTION}

\section{OPEN ACCESS}

Edited by:

Gianni Ciofani,

Politecnico di Torino, Italy

Reviewed by:

Luca Ceseracciu,

Fondazione Istituto Italiano di

Technologia, Italy

Giulia Suarato,

Fondazione Istituto Italiano di

Technologia, Italy

Piergiorgio Gentile,

Newcastle University, United Kingdom

${ }^{*}$ Correspondence:

Ilaria Elena Palamà

ilaria.palama@nanotec.cnr.it

Barbara Cortese

barbara.cortese@nanotec.cnr.it

Specialty section:

This article was submitted to

Nanobiotechnology,

a section of the journal

Frontiers in Bioengineering and

Biotechnology

Received: 01 August 2018 Accepted: 03 September 2018

Published: 24 September 2018

Citation:

Palamà IE, D'Amone $S$ and Cortese B (2018) Microenvironmental Rigidity of $3 D$ Scaffolds and Influence on Glioblastoma Cells: A Biomaterial

Design Perspective.

Front. Bioeng. Biotechnol. 6:131.

doi: 10.3389/fbioe.2018.00131
Glioblastoma (GBM), or grade IV glioma, is an extremely aggressive tumor that infiltrates through the brain leaving the patient with a median survival time from 12 to 15 months (Ostrom et al., 2013). Individual aspects of the microenvironment features play a critical role on GBM cell dynamics and treatment resistance (Bellail et al., 2004; Zamecnik, 2005; Calabrese et al., 2007). Because of GBM's aggressive and invasive behavior, inhibition of GBM migration is envisaged as an important therapeutic objective (Bravo-Cordero et al., 2012; Wells et al., 2013). However, current models fail to account for the complex brain microenvironment. The demand of preclinical models that can faithfully mimic the clinical scenario may bridge the discrepancy between preclinical and clinical data and aid to develop treatments that are more effective.

The extracellular matrix (ECM) of the GBM microenvironment is constitutively composed of the polysaccharide hyaluronic acid (HA), and in a distinctive minor degree of tenascin-C, collagen IV and V, fibronectin, and laminin (Giese and Westphal, 1996; Rape et al., 2014). Also, typically with high glioma grade, the HA's cellular receptor CD44 is overexpressed, suggesting that CD44enriched cells invade more efficiently the brain parenchyma (Bellail et al., 2004). GBM malignancy is furthermore promoted through interactions with the other aforementioned ECM components through different biochemical pathways (Sarkar et al., 2006; Lathia et al., 2012), which trigger an increase of the concentration of the non-cellular components (Bellail et al., 2004; Lathia et al., 2012). This increased density of the tumor ECM consequently increases the mechanical stiffness of the microenvironment (Ananthanarayanan et al., 2011; Wiranowska and Rojiani, 2011; Pathak and Kumar, 2012; Pedron and Harley, 2013; Kim and Kumar, 2014; Umesh et al., 2014; Heffernan et al., 2015).

In our opinion, to gain further insights into tumor invasiveness, heterogeneity and treatment resistance, we have to look more deeply at how cell behavior is influenced by matrix stiffness (a process known as mechanotaxis or durotaxis) (Lo et al., 2000; Cortese et al., 2009; Palamà et al., 2012, 2016).

\section{WHAT IS THE INFLUENCE OF THE 3D SCAFFOLD MECHANICAL PROPERTIES?}

Notably, 2D platforms do not adequately mimic the in vivo tumor environment. Recent work has focused on 3D scaffolds and matrix influence on cells with different materials and cells, as reported in Table 1. However, inconsistencies on how 3D scaffold stiffness affect cell proliferation and influence drug delivery and treatment resistance have been reported in literature 
(Wang et al., 2014, 2016; Heffernan et al., 2015; Pedron et al., 2015; Lv et al., 2016; Palamà et al., 2017). In order to tune the mechanical properties of different materials, the most common methods are (1) altering the crosslink density and (2) changing the base polymer concentration which both influence different parameters, such as the ECM architecture, stiffness, pore size, diffusion of soluble factors of the scaffolds, and ligand density. A 3D culture platform that aims to mimic the native GBM microenvironment has also the additional requirement of containing HA. Pure HA lacks mechanical strength and the ability to promote cell adhesion due to its anionic properties (Wang et al., 2012). Moreover, it does not allow control over mechanical stiffness. These downsides have been partly overcome by using synthetic ECM polymers (Lutolf and Hubbell, 2005; Seliktar, 2012). One semi-synthetic material, predominantly used to independently tune the stiffness of the scaffold, is HA-based hydrogel functionalized to favor cell adhesion. For example, Ananthanarayanan studied HA gels of varying stiffness embedded with GBM spheroids and corroborated that their invasive capacity and morphological patterns were similar to what was seen in vivo in human brain slices, in opposition to glioma cells cultured in $2 \mathrm{D}$ and $3 \mathrm{D}$ collagen contexts (Ananthanarayanan et al., 2011). Differences were theorized to be related to the variation of expression of CD44. This was confirmed by Harley and co-workers, who identified CD44 as a key driver of glioma malignancy with cells encapsulated in gelatin and PEG-based hydrogels grafted with a HA hydrogel network (Pedron et al., 2013). Analogous observations were made by Erikson using porous chitosan-hyaluronic acid scaffolds of different stiffness, obtained varying the chitosan content. With a higher polymer content, the pore walls were thicker, with reduced interconnections between pores as well as the pore size (Erickson et al., 2018). Stiffness was shown to influence the morphology of the cell aggregates as well as the expression of

TABLE 1 | A summary of various scaffolds used for glioblastoma responses.

\begin{tabular}{|c|c|c|c|c|c|}
\hline Scaffolds & Stiffness value range & Porosity & Cells & Behavior & References \\
\hline Chitosan/hyaluronic acid & $\begin{array}{l}\text { Tunable between } \mathrm{kPa} \\
\text { to } \mathrm{MPa}\end{array}$ & $\begin{array}{l}77.31 \mu \mathrm{m} \text { with } 87.09 \% \\
\text { porosity; pore diameters } \\
\text { between } 134 \text { to } 179 \mu \mathrm{m}\end{array}$ & $\begin{array}{l}\text { U-118MG; GBM6 tumors; } \\
\text { U87MG }\end{array}$ & Tumor spheroid formation & $\begin{array}{l}\text { (Florczyk et al., 2013; Cha } \\
\text { et al., 2016; Kievit et al., } \\
\text { 2016; Wang et al., 2016; } \\
\text { Erickson et al., 2018) }\end{array}$ \\
\hline $\begin{array}{l}\text { Hyaluronic } \\
\text { acid-methacrylate hydrogel }\end{array}$ & $\begin{array}{l}\text { Ranging from } 50 \mathrm{~Pa} \text { to } \\
35 \mathrm{kPa}\end{array}$ & $\begin{array}{l}\text { Mesh sizes ranging from } \\
50 \text { to } 150 \mathrm{~nm}\end{array}$ & $\begin{array}{l}\text { Human U373-MG and } \\
\text { U87-MG; rat C6 glioma }\end{array}$ & $\begin{array}{l}\text { GBM cell morphology and } \\
\text { motility are regulated by } \\
\text { stiffness. Different GBM } \\
\text { invasiveness C6 > U87-MG } \\
>\text { U373-MG }\end{array}$ & $\begin{array}{l}\text { (Ananthanarayanan et al., } \\
\text { 2011) }\end{array}$ \\
\hline $\begin{array}{l}\text { Gelatin methacrylate } \\
\text { hydrogel }\end{array}$ & Ranging from 5 to $55 \mathrm{kPa}$ & Micron scale larger & U87-MG & $\begin{array}{l}\text { Biophysical regulation of } \\
\text { GBM cell activity is not } \\
\text { direct or clear }\end{array}$ & (Pedron and Harley, 2013) \\
\hline $\begin{array}{l}\text { Poly(ethylene-glycol) } \\
\text { (PEG)-based hydrogels }\end{array}$ & Ranging from 1 to $26 \mathrm{kPa}$ & - & U87-MG & Tumor spheroid formation & $\begin{array}{l}\text { (Pedron et al., 2013; Wang } \\
\text { et al., 2014) }\end{array}$ \\
\hline Polyacrylamide hydrogels & $\begin{array}{l}\text { Ranging from } 0.2 \text { to } 50 \\
\mathrm{kPa}\end{array}$ & - & $\begin{array}{l}\text { Patient derived GBM cells } \\
\text { (JK2, SJH1, WK1, RN1 } \\
\text { and PR1) }\end{array}$ & $\begin{array}{l}\text { Different migratory capacity. } \\
\text { No detected association } \\
\text { between cell morphology } \\
\text { and migratory capacity }\end{array}$ & (Grundy et al., 2016) \\
\hline $\begin{array}{l}\text { Temperature responsive } \\
\text { poly(N-isopropylacrylamide- } \\
\text { co-Jeffamine } \mathrm{M} \text {-1000 } \\
\text { acrylamide) }\end{array}$ & $\begin{array}{l}\text { Tunable between } 153 \text { and } \\
1,240 \mathrm{~Pa}\end{array}$ & - & $\begin{array}{l}\text { Patient-derived GSC cell } \\
\text { lines }\end{array}$ & $\begin{array}{l}\text { On soft scaffolds } \\
\text { (153-325 Pa), GSCs did not } \\
\text { cluster into large } \\
\text { neurosphere }\end{array}$ & (Heffernan et al., 2017) \\
\hline $\begin{array}{l}\text { Chitosan-alginate scaffold } \\
\text { coated with hyaluronic acid }\end{array}$ & - & - & U-87MG & Tumor spheroid formation & (Kievit et al., 2016) \\
\hline $\begin{array}{l}\text { GBM patient tissue derived } \\
\text { ECM }\end{array}$ & $78.09 \pm 29.22 \mathrm{~Pa}$ & $\begin{array}{l}\text { Porous and fibrous } \\
\text { structure }\end{array}$ & Patient-derived GBM cells & $\begin{array}{l}\text { GBM cells exhibited } \\
\text { heterogeneous morphology } \\
\text { and altered the invasion } \\
\text { routes in a } \\
\text { microenvironment-adaptive } \\
\text { manner }\end{array}$ & (Koh et al., 2018) \\
\hline $\begin{array}{l}\text { Gelatin/alginate/fibrinogen } \\
\text { hydrogel }\end{array}$ & - & - & GSC cell lines & $\begin{array}{l}\text { GSC did not maintain their } \\
\text { characteristics of cancer } \\
\text { stem cells but showed } \\
\text { differentiation potential }\end{array}$ & (Xingliang et al., 2016) \\
\hline Collagen based hydrogel & Tunable stiffness & $\begin{array}{l}\text { Tunable between } 30 \text { and } \\
100 \mu \mathrm{m}\end{array}$ & $\begin{array}{l}\text { U87, U251 and HS683 } \\
\text { cell lines; primary glioma } \\
\text { cells (OSU-2); patient }\end{array}$ & $\begin{array}{l}\text { Enhancement the } \\
\text { malignancy of the glioma } \\
\text { cells; spheroid formations }\end{array}$ & $\begin{array}{l}\text { (Rao et al., 2013; Cha et al., } \\
\text { 2016; Lv et al., 2016; Jia } \\
\text { et al., 2018) }\end{array}$ \\
\hline
\end{tabular}

derived GBM stem cells 
drug resistance, hypoxia, and invasion-related genes (Mih et al., 2011; Zustiak et al., 2016; Erickson et al., 2018).

\section{TYPE OF CELLS USED IN THE IN VITRO MODELS}

A further critical key parameter is the choice of the cells used (Zustiak et al., 2014). Typically, commercially available human tumor cell lines are used, but they neglect predicting clinical outcomes due to different genetic aberrations. Glioblastoma stem-like cells (GSC) can mimic the tumor of origin being tumor cells with stem cell properties (Saha et al., 2008). However, they require isolating stem cells from each tumor patient and expansion to an adequate number within a clinically acceptable time. Aggregated cultures would recapitulate better the GBM microenvironment, allowing cell-cell contacts and collective migration. Non-adherent cultures lack the cell-matrix interactions present in the tumor stroma, whereas complex spherical cancer models (i.e. non-adherent cancer cell linederived spheroids, or spheroids derived from primary tumor dissociation) can promote cell-cell interactions. The use of patient-derived cells cultured as neurospheres is a significant advance respect to glioma cell lines (Rao et al., 2013; Cha et al., 2016) however they do not accurately reproduce the original tumor composition due to heterogeneity loss and lack of an adhesive matrix. A solution could be represented by GBM organoids (Hubert et al., 2016), although these require months for generation, thus becoming useless in aid of patient treatment and not necessarily being an improvement to the patient outcomes (Oh et al., 2014), whereas neurosphere cultures can be established within only few weeks.

\section{INFLUENCE OF COMPOUNDING STIMULI ON THE SCAFFOLDS}

Diverging results have also been implicated with the matrix metalloprotease (MMP) secretion. For example, an increase of MMP-9 production in hyaluronic acid-based hydrogels with increasing stiffness was reported by Pedron's group while Wang and colleagues described an opposite behavior (Pedron et al., 2013, 2015; Wang et al., 2014). The reason, in our opinion, is related to the difficulty to discriminate the role of stiffness or of the biochemical stimuli on cell invasion. In fact, only a few works report a selected degree of decoupling of the mechanical properties, porosity, and/or biochemical cues. The interference of other compounding stimuli in the design of functional cell culture substrates should be minimized if not isolated. Changes in the ligand density and the pore size of the matrix may obstruct migration of cells and alter solute diffusion (Shu et al., 2002). For example, Cha used a different molecular weight of

\section{REFERENCES}

Ananthanarayanan, B., Kim, Y., and Kumar, S. (2011). Elucidating the mechanobiology of malignant brain tumors using a brain matrix-mimetic
HA to simply coat the collagen I fibers without modifications and crosslinking (Cha et al., 2016). Using a higher molecular weight and 3D structure of the polymer may have induced different cell responses. Rao reported a high degree of thiolation, which may have altered the bioactivity of the substrate (Rao et al., 2013). Kumar and co-workers managed to decouple the effects by assembling hydrogel networks of collagen I and agarose and increasing the stiffness by increasing the concentration of non-adhesive agarose while keeping collagen I levels constant (Ulrich et al., 2010). However, increasing the concentration of agarose may result in smaller pores that restricted migration on stiffer hydrogels. Moreover, the presence of the agarose interfering with collagen fiber deformation and bundling may have thereby restricted local ability of tumor cells to stiffen their microenvironment (Kilian and Mrksich, 2012; Rape et al., 2015).

In conclusion there is still no existing artificial GBM microenvironment which can replace an in vivo model. It is essential to ask if it is worth to increase the complexity of the ECM microenvironment and to define which parameters are at least required to achieve a physiologically relevant model ex vivo. We think that tuning matrix stiffness will be pivotal at both a preclinical and clinical level, to move forward this field of investigation of cell behavior during tumorigenesis thereby providing an important tool to target and investigate the more effective therapy at different stages of cancer progression. To unravel the tumor invasiveness and to demonstrate their clinical value, a fully comprehensive analysis approach has to be achieved. This invites further study and highlights the importance of conducting parallel measurements using spheroid cell lines in highly multistructured conditions as well as comparisons with patient outcomes.

\section{AUTHOR CONTRIBUTIONS}

IP, SD, and $\mathrm{BC}$ wrote the manuscript. All authors reviewed the manuscript and have given approval to the final version of the manuscript.

\section{FUNDING}

FIRS project Tecnopolo di nanotecnologia e fotonica per la medicina di precisione (grant no: CIPE n. 78/2017 B83B17000010001).

\section{ACKNOWLEDGMENTS}

This study is supported by the Italian Association for Cancer Research (AIRC) through the grant MFAG n. 16803 and partially by the FIRS project Tecnopolo di nanotecnologia e fotonica per la medicina di precisione.

hyaluronic acid hydrogel platform. Biomaterials 32, 7913-7923. doi: 10.1016/j.biomaterials.2011.07.005

Bellail, A. C., Hunter, S. B., Brat, D. J., Tan, C., and Van Meir, E. G. (2004). Microregional extracellular matrix heterogeneity in brain 
modulates glioma cell invasion. Int. J. Biochem. Cell Biol. 36, 1046-1069. doi: 10.1016/j.biocel.2004.01.013

Bravo-Cordero, J. J., Hodgson, L., and Condeelis, J. (2012). Directed cell invasion and migration during metastasis. Curr. Opin. Cell Biol. 24, 277-283. doi: 10.1016/j.ceb.2011.12.004

Calabrese, C., Poppleton, H., Kocak, M., Hogg, T. L., Fuller, C., Hamner, B., et al. (2007). A perivascular niche for brain tumor stem cells. Cancer Cell 11, 69-82. doi: 10.1016/j.ccr.2006.11.020

Cha, J., Kang, S. G., and Kim, P. (2016). Strategies of mesenchymal invasion of patient-derived brain tumors: microenvironmental adaptation. Sci. Rep. 6:24912. doi: $10.1038 /$ srep24912

Cortese, B., Gigli, G., and Riehle, M. (2009). Mechanical gradient cues for guided cell motility and control of cell behavior on uniform substrates. Adv. Func. Mater. 19, 2961-2968. doi: 10.1002/adfm.200900918

Erickson, A. E., Lan Levengood, S. K., Sun, J., Chang, F. C., and Zhang, M. (2018). Fabrication and characterization of chitosan-hyaluronic acid scaffolds with varying stiffness for glioblastoma cell culture. Adv. Healthcare Mater. 7:e1800295. doi: 10.1002/adhm.201800295

Florczyk, S. J., Wang, K., Jana, S., Wood, D. L., Sytsma, S. K., Sham, J., et al. (2013). Porous chitosan-hyaluronic acid scaffolds as a mimic of glioblastoma microenvironment ECM. Biomaterials 34, 10143-10150. doi: 10.1016/j.biomaterials.2013.09.034

Giese, A., and Westphal, M. (1996). Glioma invasion in the central nervous system. Neurosurgery 39, 235-250; discussion 250-232.

Grundy, T. J., De Leon, E., Griffin, K. R., Stringer, B. W., Day, B. W., Fabry, B., et al. (2016). Differential response of patient-derived primary glioblastoma cells to environmental stiffness. Sci. Rep. 6:23353. doi: 10.1038/srep23353

Heffernan, J. M., McNamara, J. B., Borwege, S., Vernon, B. L., Sanai, N., Mehta, S., et al. (2017). PNIPAAm-co-Jeffamine $\AA$ (PNJ) scaffolds as in vitro models for niche enrichment of glioblastoma stem-like cells. Biomaterials 143, 149-158. doi: 10.1016/j.biomaterials.2017.05.007

Heffernan, J. M., Overstreet, D. J., Le, L. D., Vernon, B. L., and Sirianni, R. W. (2015). Bioengineered scaffolds for 3D analysis of glioblastoma proliferation and invasion. Ann. Biomed. Eng. 43, 1965-1977. doi: 10.1007/s10439-014-1223-1

Hubert, C. G., Rivera, M., Spangler, L. C., Wu, Q., Mack, S. C., Prager, B. C., et al. (2016). A Three-dimensional organoid culture system derived from human glioblastomas recapitulates the hypoxic gradients and cancer stem cell heterogeneity of tumors found in vivo. Cancer Res. 76, 2465-2477. doi: 10.1158/0008-5472.CAN-15-2402

Jia, W., Jiang, X., Liu, W., Wang, L., Zhu, B., Zhu, H., et al. (2018). Effects of three-dimensional collagen scaffolds on the expression profiles and biological functions of glioma cells. Int. J. Oncol. 52, 1787-1800. doi: $10.3892 /$ ijo. 2018.4330

Kievit, F. M., Wang, K., Erickson, A. E., Lan Levengood, S. K., Ellenbogen, R. G., and Zhang, M. (2016). Modeling the tumor microenvironment using chitosanalginate scaffolds to control the stem-like state of glioblastoma cells. Biomater. Sci. 4, 610-613. doi: 10.1039/C5BM00514K

Kilian, K. A., and Mrksich, M. (2012). Directing stem cell fate by controlling the affinity and density of ligand-receptor interactions at the biomaterials interface. Angewandte Chemie 51, 4891-4895. doi: 10.1002/anie.2011 08746

Kim, Y., and Kumar, S. (2014). CD44-mediated adhesion to hyaluronic acid contributes to mechanosensing and invasive motility. Mol. Cancer Res. 12, 1416-1429. doi: 10.1158/1541-7786.MCR-13-0629

Koh, I., Cha, J., Park, J., Choi, J., Kang, S. G., and Kim, P. (2018). The mode and dynamics of glioblastoma cell invasion into a decellularized tissue-derived extracellular matrix-based three-dimensional tumor model. Sci. Rep. 8:4608. doi: 10.1038/s41598-018-22681-3

Lathia, J. D., Li, M., Hall, P. E., Gallagher, J., Hale, J. S., Wu, Q., et al. (2012). Laminin alpha 2 enables glioblastoma stem cell growth. Ann. Neurol. 72, 766-778. doi: 10.1002/ana.23674

Lo, C. M., Wang, H. B., Dembo, M., and Wang, Y. L. (2000). Cell movement is guided by the rigidity of the substrate. Biophys. J. 79:8. doi: 10.1016/S0006-3495(00)76279-5

Lutolf, M. P., and Hubbell, J. A. (2005). Synthetic biomaterials as instructive extracellular microenvironments for morphogenesis in tissue engineering. Nat. Biotechnol. 23, 47-55. doi: 10.1038/nbt1055
Lv, D., Yu, S. C., Ping, Y. F., Wu, H., Zhao, X., Zhang, H., et al. (2016). A three-dimensional collagen scaffold cell culture system for screening antiglioma therapeutics. Oncotarget 7, 56904-56914. doi: 10.18632/oncotarget. 10885

Mih, J. D., Sharif, A. S., Liu, F., Marinkovic, A., Symer, M. M., and Tschumperlin, D. J. (2011). A multiwell platform for studying stiffnessdependent cell biology. PLOS ONE 6:e19929. doi: 10.1371/journal.pone.00 19929

Oh, Y. T., Cho, H. J., Kim, J., Lee, J. H., Rho, K., Seo, Y. J., et al. (2014). Translational validation of personalized treatment strategy based on genetic characteristics of glioblastoma. PLoS ONE 9:e103327. doi: 10.1371/journal.pone.01 03327

Ostrom, Q. T., Gittleman, H., Farah, P., Ondracek, A., Chen, Y., Wolinsky, Y., et al. (2013). CBTRUS statistical report: primary brain and central nervous system tumors diagnosed in the United States in 2006-2010. Neurooncology 15(Suppl. 2), ii1-ii56. doi: 10.1093/neuonc/not151

Palamà, I. E., Arcadio, V., D'Amone, S., Biasiucci, M., Gigli, G., and Cortese, B. (2017). Therapeutic PCL scaffold for reparation of resected osteosarcoma defect. Sci. Rep. 7:12672. doi: 10.1038/s41598-017-12824-3

Palamà, I. E., Coluccia, A. M., Gigli, G., and Riehle, M. (2012). Modulation of alignment and differentiation of skeletal myoblasts by biomimetic materials. Integr. Biol. 4, 1299-1309. doi: 10.1039/c2ib20133j

Palamà, I. E., D'Amone, S., and Cortese, B. (2016). Mechanical Guidance of Cell Migration. Zagreb: IAPC Publishing.

Pathak, A., and Kumar, S. (2012). Independent regulation of tumor cell migration by matrix stiffness and confinement. Proc. Natl. Acad. Sci. U.S.A. 109, 10334-10339. doi: 10.1073/pnas.1118073109

Pedron, S., Becka, E., and Harley, B. A. (2013). Regulation of glioma cell phenotype in 3D matrices by hyaluronic acid. Biomaterials 34, 7408-7417. doi: 10.1016/j.biomaterials.2013.06.024

Pedron, S., Becka, E., and Harley, B. A. (2015). Spatially gradated hydrogel platform as a $3 \mathrm{D}$ engineered tumor microenvironment. Adv. Mater. 27, 1567-1572. doi: 10.1002/adma.201404896

Pedron, S., and Harley, B. A. (2013). Impact of the biophysical features of a 3D gelatin microenvironment on glioblastoma malignancy. J. Biomed. Mater. Res. A 101, 3404-3415. doi: 10.1002/jbm.a.34637

Rao, S. S., Dejesus, J., Short, A. R., Otero, J. J., Sarkar, A., and Winter, J. O. (2013). Glioblastoma behaviors in three-dimensional collagen-hyaluronan composite hydrogels. ACS Appl. Mater. Interfaces 5, 9276-9284. doi: 10.1021/am40 2097j

Rape, A., Ananthanarayanan, B., and Kumar, S. (2014). Engineering strategies to mimic the glioblastoma microenvironment. Adv. Drug Deliv. Rev. 79-80, 172-183. doi: 10.1016/j.addr.2014.08.012

Rape, A. D., Zibinsky, M., Murthy, N., and Kumar, S. (2015). A synthetic hydrogel for the high-throughput study of cell-ECM interactions. Nat. Commun. 6:8129. doi: 10.1038 /ncomms9129

Saha, K., Keung, A. J., Irwin, E. F., Li, Y., Little, L., Schaffer, D. V., et al. (2008). Substrate modulus directs neural stem cell behavior. Biophys. J. 95, 4426-4438. doi: 10.1529/biophysj.108.132217

Sarkar, S., Nuttall, R. K., Liu, S., Edwards, D. R., and Yong, V. W. (2006). Tenascin$\mathrm{C}$ stimulates glioma cell invasion through matrix metalloproteinase-12. Cancer Res. 66, 11771-11780. doi: 10.1158/0008-5472.CAN-05-0470

Seliktar, D. (2012). Designing cell-compatible hydrogels for biomedical applications. Science 336, 1124-1128. doi: 10.1126/science.1214804

Shu, X. Z., Liu, Y., Luo, Y., Roberts, M. C., and Prestwich, G. D. (2002). Disulfide cross-linked hyaluronan hydrogels. Biomacromolecules 3, 1304-1311. doi: $10.1021 / \mathrm{bm} 025603 \mathrm{c}$

Ulrich, T. A., Jain, A., Tanner, K., MacKay, J. L., and Kumar, S. (2010). Probing cellular mechanobiology in three-dimensional culture with collagen-agarose matrices. Biomaterials 31, 1875-1884. doi: 10.1016/j.biomaterials.2009.10.047

Umesh, V., Rape, A. D., Ulrich, T. A., and Kumar, S. (2014). Microenvironmental stiffness enhances glioma cell proliferation by stimulating epidermal growth factor receptor signaling. PLoS ONE 9:e101771. doi: 10.1371/journal.pone.0101771

Wang, C., Tong, X., and Yang, F. (2014). Bioengineered 3D brain tumor model to elucidate the effects of matrix stiffness on glioblastoma cell behavior using PEG-based hydrogels. Mol. Pharm. 11, 2115-2125. doi: 10.1021/mp50 00828 
Wang, K., Kievit, F. M., Erickson, A. E., Silber, J. R., Ellenbogen, R. G., and Zhang, M. (2016). Culture on 3D chitosan-hyaluronic acid scaffolds enhances stem cell marker expression and drug resistance in human glioblastoma cancer stem cells. Adv. Healthc. Mater. 5, 3173-3181. doi: 10.1002/adhm.201 600684

Wang, X., He, J., Wang, Y., and Cui, F. Z. (2012). Hyaluronic acid-based scaffold for central neural tissue engineering. Interface Focus 2, 278-291. doi: 10.1098/rsfs.2012.0016

Wells, A., Grahovac, J., Wheeler, S., Ma, B., and Lauffenburger, D. (2013). Targeting tumor cell motility as a strategy against invasion and metastasis. Trends Pharmacol. Sci. 34, 283-289. doi: 10.1016/j.tips.2013.03.001

Wiranowska, M. R., and Rojiani, M. V. (2011). Extracellular Matrix Microenvironment in Glioma Progression. Rijeka: INTECH Open Access Publisher.

Xingliang, D., Cheng, M., Qing, L., and Tao, X. (2016). 3D bioprinted glioma stem cells for brain tumor model and applications of drug susceptibility. Biofabrication 8:045005. doi: 10.1088/1758-5090/8/4/045005

Zamecnik, J. (2005). The extracellular space and matrix of gliomas. Acta Neuropathol. 110, 435-442. doi: 10.1007/s00401-005-1078-5
Zustiak, S., Nossal, R., and Sackett, D. L. (2014). Multiwell stiffness assay for the study of cell responsiveness to cytotoxic drugs. Biotechnol. Bioeng. 111, 396-403. doi: 10.1002/bit.25097

Zustiak, S. P., Dadhwal, S., Medina, C., Steczina, S., Chehreghanianzabi, Y., Ashraf, A., et al. (2016). Three-dimensional matrix stiffness and adhesive ligands affect cancer cell response to toxins. Biotechnol. Bioeng. 113, 443-452. doi: 10.1002/bit.25709

Conflict of Interest Statement: The authors declare that the research was conducted in the absence of any commercial or financial relationships that could be construed as a potential conflict of interest.

Copyright (๑) 2018 Palamà, D'Amone and Cortese. This is an open-access article distributed under the terms of the Creative Commons Attribution License (CC BY). The use, distribution or reproduction in other forums is permitted, provided the original author(s) and the copyright owner(s) are credited and that the original publication in this journal is cited, in accordance with accepted academic practice. No use, distribution or reproduction is permitted which does not comply with these terms. 